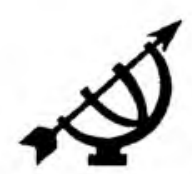

\title{
Die konstruksie van betekenis by seksuele molestering
}

\author{
R.L. van Niekerk \& H.G. Pretorius \\ Departement Sielkunde \\ Randse Afrikaanse Universiteit \\ JOHANNESBURG \\ E-pos: leonenlz@mweb.co.za \\ hgp@adfin.rau.ac.za \\ Abstract
}

The construction of meaning in sexual abuse

This article is based on the results obtained from a qualitative study undertaken with female survivors of childhood sexual abuse. The study underlying this article is grounded in social construction methodology, functioning as a metaparadigmatic context for the understanding of society's attribution of meaning to childhood sexual abuse. This article focuses on the construction of meaning relating to the survivors' experiences of childhood sexual abuse and their perceptions of these events when they were introduced to the social constructions about childhood sexual abuse in later life.

\section{Inleiding}

Seksuele molestering is een vorm van geweld teen kinders wat wêreldwyd toeneem. In Suid-Afrika is die seksuele molestering van kinders ook aan die toeneem (Mabusela, 1994:177). Benaderde aanduidings vir die wêreldwye voorkoms van kindermolestering wissel van tussen $7 \%$ tot $36 \%$ vir vrouens en tussen $3 \%$ tot $29 \%$ vir mans (Barnett et al., 1997:75). Statistiek wat oor misdaad teen kinders op 'n konferensie aangebied deur die Suid-Afrikaanse Polisiediens, bekendgemaak is, dui daarop dat 33827 misdade teenoor kinders vir 1998 aangemeld is. Hiervan is 14 225 in die eerste 11 maande van die jaar verkrag, 679 is gesodomiseer en 171 was die slagoffers van bloedskande (Anon., 1999a; Anon., 1999b). Die getal aanmeldings by die Suid-Afrikaanse Polisiediens vir seksuele gemeenskap met meisies onder die voorgeskrewe wetlike ouderdom van 16 jaar, was 474 (Misdaadinligtinganalisesentrum, 1999:45) 
Kinders wil graag sin maak en betekenis vind wanneer hulle seksueel gemolesteer word (MacLeod \& Saraga, 1988). Hulle verstaan dikwels nie wat met hulle gebeur nie, aangesien hulle op 'n jong ouderdom nog nie die toepaslike seksuele kennis bekom het nie. Miltenburg en Singer (1997:42) dui aan dat kinders wat seksueel gemolesteer is, basiese aannames, teorieë en patrone om aksie te neem ontwikkel, ten einde hulle emosies en die omgewing waarin die molestering plaasvind, te kan hanteer. Jehu et al. (1986:49) toon aan dat vroue wat as kinders seksueel gemolesteer is, sekere idees aangaande die gebeurtenis huldig wat bydra tot vele probleme in hulle volwasse lewe.

Hierdie artikel is 'n weergawe van 'n kwalitatiewe studie wat die wyse uitbeeld waarop drie Suid-Afrikaanse vroue betekenis aan die gebeurtenisse geheg het toe hulle as kinders seksueel gemolesteer is. Die artikel is gegrond op die metodologie van die sosiale konstruksionisme, wat funksioneer as ' $n$ metaparadigmatiese konteks vir die bestudering van die betekenisse wat sosiale gemeenskappe aan die konstruk "seksuele molestering" heg. In die artikel word die betekenisse wat die vroue aan hulle seksuele molestering geheg het, verwoord (persoonlike konstruksie van betekenis). Verder word ook dit wat hulle ervaar het toe hulle gekonfronteer is met die betekenis wat die sosiale gemeenskap aan die konstruk heg (sosiale konstruksie van betekenis), ontleed.

\section{Sosiale konstruksionisme as paradigmatiese konteks}

Die sosiale konstruksie van realiteit is 'n benadering om menslike gedrag te verklaar wat aanvanklik deur Berger en Luckmann (1966) begin is. Die sosiale konstruksionisme het intussen ontwikkel as 'n postmoderne benadering in die psigologiese en sosiologiese vakwetenskappe - 'n ontwikkeling wat daarop dui dat gemeenskappe betekenisse aan konstrukte en hulle realiteit gee. Mense ko-konstrueer hulle realiteit deur middel van taal en betekenisse word dus gekonstrueer wanneer mense met mekaar kommunikeer (Atwood, 1997:31). Burr (1999:4) konkludeer dat die wyse waarop mense die wêreld om hulle verstaan nie 'n produk van objektiewe waarneming is nie, maar wel die produk van sosiale prosesse en interaksies waarin mense konstant in kontak met mekaar is. Die betekenisse wat mense aan konstrukte heg, is daarom ook histories en kultureel relatief.

Owen (1992:385) beskryf sosiale konstruksionisme as die benadering wat daarop dui dat abstrakte idees, mense se verhoudings in verband daarmee en die verhoudings waarin hulle leef, mensgemaakte prosesse en kontekste is. Hulle word in die kontekste gebore, of verkry toegang daartoe vanwee hulle status in die gemeenskap (Atwood, 1997:18). 
R.L. van Niekerk \& H.G. Pretorius

Hierdie benadering omsluit ander teorieë wat as verklarings dien vir die wyse waarop en die redes waarom mense bepaalde kulturele, sosiale en persoonlike betekenisse ontwikkel. Op hierdie gronde stel Berg en De Jong (1996:388) dat sosiale konstruksionisme 'n metateorie aangaande mense se interpretasies van die wêreld en hulle ervarings is. Hoffman (1990 4) is van mening dat die teorie van sosiale konstruksie dien as 'n lens om die lense van ander te kan sien.

Die sosiale konstruksionisme is gefundeer in die aanname dat kennis en betekenis deur gemeenskappe gekonstrueer word. Betekenis ontstaan op grond van 'n idee wat in 'n gemeenskap vorm aanneem en uiteindelik op een of ander wyse gevestig raak (Atwood, 1997:14). Op dié wyse het pre-moderne, moderne en postmoderne gemeenskappe kennis en betekenis deur die eeue gekonstrueer en gevestig

- In pre-moderne gemeenskappe is kennis deur God geopenbaar en in die gemeenskappe bekendgemaak deur profete, priesters en ander tussengangers. Hierdie kennis het gevestig geraak in verskeie godsdiensgroepe (onder andere kerke) wat die betekenis van konstrukte bepaal.

- In modernistiese gemeenskappe is kennis deur middel van wetenskaplike ondersoek op empiriese wyse ontdek. Hierdie kennis het gevestig geraak in verskeie belangegroepe (soos onder andere die Psigoanaliste of die Behavioriste of die Fenomenoloë) en gemeenskapsinstellings (soos onder andere universiteite of navorsingsinstansies). Hierdie instellings gee weer op hulle beurt 'n unieke betekenis aan konstrukte binne die konteks van oorsaak en gevolg

- In postmoderne gemeenskappe word daarvan uitgegaan dat kennis in gemeenskappe geko-konstrueer word. Hier is dit nie van belang wat die produk van kennis is nie, maar wel wat die proses is waarvolgens kennis gekonstrueer word (Gergen, 1994). Taal en die betekenis van woorde speel in hierdie opsig 'n belangrike rol in die konstruksie van betekenis.

In hierdie artikel word ondersoek ingestel na die wyse waarop die deelnemers aan die voorafgaande studie betekenis aangaande hulle seksuele molestering gekonstrueer het. Die rol wat die oortreder speel, is van wesenlike belang, aangesien die kind uit sy optrede en verduidelikings betekenis gee aan dit wat met haar gebeur. Wells (1986) gee 'n sistematiese uiteensetting van die proses en die rol wat die ouerfiguur en ander volwassenes in die kind se konstruksie van betekenis speel. Die rol van die gemeenskap is ook belangrik, omdat die betekenis wat die gemeenskap aan seksuele molestering gee, die kind 
later in konfrontasie bring met die betekenis wat sy aan die gebeurtenis toegeskryf het.

\section{Seksuele molestering}

\subsection{Die definiëring van seksuele molestering}

Die definiëring van seksuele molestering lewer verskeie probleme op. Barnett et al. (1997:73) illustreer die probleem met verskeie voorbeelde wat daarop dui dat verskillende gemeenskappe verskillende betekenisse heg aan die tipe dade wat as seksuele molestering gedefinieer kan word.

In pre-moderne gemeenskappe is bepaalde vorme van seksuele kontak tussen familielede verbied (bv. in Levitikus 18 en 20). Dit blyk dat bloedskande van die eerste verbode seksuele kontak tussen familielede was, maar dat dit in sommige koningshuise wel geduld was (Nevid et al., 1995:12). In die antieke Hebreeuse kultuur kon mans reeds met meisies van 13 jaar trou (Förster, 1964:127). In antieke Griekeland is homoseksuele verhoudings tussen volwasse mans en adolessente seuns algemeen aanvaar en nie as seksuele molestering van 'n minderjarige beskou nie (Masters et al., 1992:346). In terme van die huidige wetgewing in Suid-Afrika sou die gebeurtenisse as 'n misdaad beskou kon word, aangesien seksuele gemeenskap met ' $n$ meisie onder die ouderdom van 16 jaar of sodomie met 'n seun onder 19 jaar, deur wetgewing verbied word (Wet no. 23 van 1957).

Modernistiese definisies van seksuele molestering is gegrond op wetenskaplike navorsingsmetodes, wat beteken dat die meeste definisies van seksuele molestering operasionele definisies is (Barnett et al., 1997:74). Die meeste definisies beskryf die seksuele molestering van kinders in terme van die magsmisbruik van 'n volwassene (Gilgun, 1994: 468), of seksuele kontak tussen 'n volwassene en 'n kind (Barnett et al., 1997: 73), of as wetlik verbode dade (Wet no 23 van 1957).

Postmoderne definisies van seksuele molestering word veral deur die feminisme en die sosiale konstruksionisme geformuleer. Die feminisme beskryf die seksuele molestering van kinders in drie sleutelterme, naamlik die misbruik van vertroue en verantwoordelikheid, die misbruik van mag en die onvermoë van kinders om tot so 'n daad toe te stem (Macleod \& Saraga, 1988).

Die sosiale konstruksionisme stel dat die definiëring van seksuele molestering bepaal word deur persoonlike idees en die sienings in die sosiale gemeenskap van wat seksuele molestering impliseer. Definisies word geformuleer wanneer seksuele molestering as 'n sosiale probleem geïdentifiseer word (Barnett et al., 1997:6). Postmodernistiese definisies 
R.L. van Niekerk \& H.G. Pretorius

is dus nooit staties nie, omdat dit beïnvloed word deur verskillende ervarings en konstruksies van mense en gemeenskappe. 'n Definisie van seksuele molestering vanuit sosiaal-konstruksionistiese perspektief kan dus soos volg geformuleer word:

Die seksuele molestering van kinders is 'n relatiewe envaring van ontoepaslike seksuele dade wat 'n gemeenskap nie tussen 'n volwassene en 'n kind verwag nie. Hierdie dade hou relatiewe gevolge in op grond van die persoonlike en gemeenskaplike konstruksies van daardie seksuele ervaring.

\subsection{Die sosiale konstruksie van seksuele molestering}

Seksualiteit is die produk van sosiale konstruksie, waarin mag 'n beduidende rol speel, veral in die wyse waarop seksuele gedrag manifesteer (Kritzinger, 1995:194). Seksuele molestering kan gevolglik beskou word as 'n daad om manlike dominansie uit te druk en vroulike onderdanigheid af te dwing deur seksualiteit. Verskeie instellings en diskoerse in die samelewing speel 'n rol om diè magswanbalans in stand te hou:

- Opvoedingspatrone kan daartoe bydra. Kinders word dikwels geleer om gesag blindelings en sonder bevraagtekening te gehoorsaam. Dit plaas die molesteerder in ' $n$ posisie om mag te misbruik (Marshall \& Herman, 1998:44)

- Alhoewel godsdienstige instellings nie vir seksuele molestering geblameer kan word nie, plaas hulle mans dikwels in 'n gunstige posisie om hulle mag te misbruik. Verkeerde interpretasie oor die man as "hoof van die vrou" (Efesiërs 5:23) en "heerser oor die vrou" (Genesis 3:16) en die gehoorsaamheidseis vir kinders (Eksodus 20:12) kan aanleiding gee tot magsmisbruik.

- Die regsisteem is dikwels bevooroordeeld teenoor vroue deur hulle te blameer vir ' $n$ bepaalde aandeel (bv. uitlokkende kleredrag) in die oortreder se besluit om ' $n$ misdaad te pleeg (Marshall \& Herman, 1998:45)

- Levett (1988) dui aan dat die media 'n magtige agent in die konstruksie van dominante diskoerse is. Kinderpornografie is byvoorbeeld 'n tipe media wat kinders as seksuele modelle uitbeeld en as 'n stimulasie vir seksuele belangstelling in kinders dien (Barnett et al., 1997:95).

Alhoewel seksuele molestering deur sosiale instellings afgewys word as onaanvaarbare seksuele gedrag, dui Mabusela (1994:178) aan dat dit vir 
'n lang periode stilweg as 'n misdaad in Suid-Afrika aanvaar is. Vir die meerderheid kinders was seksuele molestering ' $n$ familiegeheim wat min of meer verdra moes word. Kinders wat slagoffers van seksuele molestering was, is in die sosiale gemeenskap gebrandmerk as "gebruikte goedere" (Kritzinger, 1988:80) en neem dikwels rolle in wat lei tot hulle reviktimisering (Dixon, 1998:209). Aan die ander kant dui die heersende diskoerse met betrekking tot die oortreder daarop dat die sosiale gemeenskap die blaam vir sulke misdade dikwels van die man na die vrou verplaas. Mans wat hulle seksuele maritale regte ontneem word, rig dit op die naaste beskikbare bron vir gratifikasie, naamlik 'n afhanklike kind (Dominelli, 1989:292). In sulke argumente word die vrou uitgesonder as die skuldige. Dit dien verder die man se optrede te regverdig en selfs te verontskuldig indien hy ontoepaslike seksuele bevrediging in kindermolestering vind wanneer sy vrou hom dit ontsê.

\section{Die wyse waarop betekenis gekonstrueer word tydens seksuele molestering}

Drie volwasse vroue wat as kinders seksueel gemolesteer is, het deelgeneem aan die ondersoek waarop hierdie artikel gebaseer is. Hulle ervarings en die betekenis wat hulle aan daardie gebeurtenisse geheg het, word in dié artikel gerapporteer. Al drie deelnemers, Mart ('n 36jarige en Afrikaanssprekend), Chanene ('n 31-jarige en Engelssprekend) en Brandy ('n 22-jarige en Sothosprekend) (al drie skuilname) is seksueel gemolesteer deur belangrike persone in hulle lewens.

Mart kom uit 'n tradisionele outoritêre ouerhuis, waar sy as kind geleer is om haar aan ouerlike gesag te onderwerp. Haar pa, as hoof van die huis, se woord was finaal en haar ma, as versorger van die gesin, het haar ook daaraan onderwerp. Mart is seksueel deur haar pa gemolesteer. Haar eerste ervaring van seksuele molestering was op 13-jarige ouderdom en dit het vir twee jaar daarna aangehou. Die seksuele molestering het die vorm van masturbasie aangeneem en van tyd tot tyd het haar pa probeer om haar seksueel te penetreer. Tans is Mart vir 'n derde keer getroud. Sy en haar man het onlangs 'n kind aangeneem.

Chanene is ook seksueel deur haar pa gemolesteer. Hy was 'n brutale man, wat haar in sy woedebuie voor haar ma verkrag het. Die molestering het op sesjarige ouderdom begin en op agtjarige ouderdom opgehou, toe hy gearresteer en gevonnis is. Hy het haar dikwels met 'n mes teen die keel gedreig wanneer hy haar seksueel gemolesteer het. Hy was werkloos en het op hierdie wyse probeer om haar ma se maandelikse salaris vir homself op te eis. Op dié wyse kon hy sy afhanklikheid van verskeie middels (alkohol en dwelms) instandhou. 
R.L. van Niekerk \& H.G. Pretorius

Chanene is ' $n$ enkelloper en het na twee mislukte verhoudings besluit om nie weer verhoudings met mans aan te knoop nie.

Brandy is met haar pa se medewete seksueel deur ' $n$ vriend van die gesin gemolesteer. Hy was 'n getroude polisieman wat haar met sy dienspistool afgedreig het om seksueel met hom te verkeer. Haar molestering het op sewejarige ouderdom begin en op 15-jarige ouderdom opgehou toe sy hom meegedeel het dat sy van hom swanger geraak het. Hy het daarna uit die gesin se lewe verdwyn. Sy is tans 'n enkelouer en maak haar kind groot met die hulp van haar grootouers.

In-diepte-onderhoude is met die deelnemers gevoer om te bepaal watter betekenis hulle uit hulle ervarings gekonstrueer het. Hulle eie woorde dien as beskrywing van wat hulle beleef het. Die onderhoude met die respondente is op band geneem, getranskribeer en respondente wat Engelssprekend is se mondelinge weergawe is in Afrikaans vertaal. Uit die teks is relevante temas met betrekking tot die konstruksie van betekenis geidentifiseer en word met verbatumvoorbeelde uit die teks gerapporteer.

\subsection{Verwarring as aanvanklike reaksie op hulle seksuele molestering}

Al drie deelnemers was aanvanklik verward oor dit wat met hulle gebeur het.

Mart: "Ek het nie geweet wat hy doen nie. Daar was hierdie man ... en ek dink die dag toe dit my tref ... dat wat hy gedoen het, verkeerd was, het my probleme begin."

Chanene: "Ek het gewonder hoekom my pa my so seermaak en ek het gewonder hoekom my ma so histeries word. Ek kon nie verstaan waarom my ma nie iets gedoen het om my te help nie, hoekom hy ' $n$ mes teen my keel moes druk en wat hy daar onder gedoen het wat so seer is nie. Ek kon dit nie verstaan nie, al wat ek geweet het, was dat dit seer was as hy my gegryp het."

Brandy: "Aanvanklik was dit, ek was verward. Ek het nie eintlik geweet wat gaan aan nie."

Die verwarring as aanvanklike reaksie op seksuele molestering is verstaanbaar, aangesien 'n seksuele ervaring vir hulle vreemd was op die ouderdom toe dit plaasgevind het. Hulle moes betekenis vind in 'n seksuele gebeurtenis waarvan hulle op daardie tydstip van hulle lewe nog nie toepaslike inligting gehad het nie. Chanene se verwarring is ook 
Die konstruksie van betekenis by seksuele molestering

verstaanbaar binne die geweldadige konteks waarin sy seksueel gemolesteer is.

\subsection{Die deelnemers se persoonlike konstruksie van betekenis aangaande hulle seksuele molestering as kinders}

Alhoewel Mart aanvanklik nie geweet het wat met haar gebeur nie, het sy later gedink dat haar ervarings van seksuele molestering gebeurtenisse is wat normaalweg elke dag tussen 'n pa en sy dogter plaasvind.

Mart: "Die tyd toe dit in die motor gebeur het, het ek gedink dit is hoe dit met Chrissie (skuilnaam) dit is my oudste suster, is. Hierdie is goeters wat ' $n$ pa met sy dogters doen. Dit was my verantwoordelikheid om vir my pa te wag en beskikbaar te wees vir my pa wanneer hy dit wil doen."

Sy het later begin dink dat haar pa besig is om haar op te voed. Toe hy skielik na twee jaar ophou, het sy gedink dat sy seker genoeg geleer het. Mart het op dié wyse 'n opvoedkundige waarde aan die gebeurtenis geheg. In daardie stadium van haar lewe was dit die betekenis wat sy met die somtotaal van haar taal en woordeskat in die gebeurtenis kon vind.

Mart: "Toe hy gestop het, het ek gedink miskien is ek nou oud en groot genoeg. Miskien het hy my nou geleer wat ek moes geweet het. Ek het nooit met my ma gepraat oor dit wat gebeur het nie. As 'n kind het ek gedink my pa was gekies om dit met my te doen, om my van die lewe te leer. Ek het dit op dié manier benader. Ja, ek het alles geglo wat hy gesê het. Die kinders in ons Sondagskool het aan sy lippe gehang en was mal oor hom. Hy het 'n manier gehad om met hulle te werk."

Chanene het op drie maniere betekenis uit haar ervaring van seksuele molestering probeer maak. Sy het gedink dit is haar straf vir iets wat sy verkeerd gedoen het, dit was haar pa se manier om haar ma se geld in die hande te kry vir drank en derdens was dit haar manier om haar ma te beskerm teen haar pa.

Chanene: "Die manier waarop hy my ma hanteer het en die dinge wat sy moes doen om hom tevrede te stel ... Ek het gedink dit was my straf. Ek het seker iets verkeerd gedoen, dit is hoekom ek gestraf word daarvoor. Ek het altyd gedink dit is die manier hoe ek volgens hom gestraf moes word. Ek het dit verdien." 
R.L. van Niekerk \& H.G. Pretorius

Chanene: "... en jy dink hy doen dit om jou ma se geld te kry tot hy tevrede is. Hy het my basies gebruik om my ma terug te kry. Hy het geweet my ma is baie lief vir my, want sy het my amper verloor toe ek gebore is. Hy het my basies misbruik as 'n vrou. Hy het gemaak dat ek mans nie vertrou nie."

Chanene: "Ja, en om my ma te help. Ek moes sterk wees vir haar. Wat my die seerste maak, is dat my ma moes swaar kry uit dit. Ek was ses jaar oud toe ek gedink het om my ma te red. Tot ek agt jaar oud was, het ek steeds geglo dat dit my verantwoordelikheid was om my ma van hom te red."

Chanene het die drieledige betekenis in hierdie dade gevind deur die optrede van haar pa te evalueer, die pyn wat sy ervaar het as straf te beleef en die rol wat sy ingeneem het om haar ma te beskerm.

Brandy het haar vertroue op die oortreder geplaas en sy molestering as deel van die normale daaglikse lewe van 'n meisie aanvaar - iets wat sy geheim moes hou

Brandy: "Ek het ook gewonder waarom ek so bloei en of dit met ander meisies ook gebeur. Ek het ook op 'n punt gekom waar ek net opgegee het jy weet. Ek het hom net laat doen wat hy ook al wou doen en soms, om eerlik te wees, het ek hom gevra om dit te doen. Ek het gedink, okay, dit is wat met ander meisies gebeur, want as dit nie gebeur nie, dan sou ek daarvan geweet het of hulle sou my gesê het. So ek het by 'n punt gekom waar ek opgegee het en op 'n manier het ek gedink dit is die regte ding om te doen, jy weet."

Brandy: "... en van wat ek gedink het, was dat dit heeltemal normaal is en dat dit met almal gebeur het en dat niemand daaroor gepraat het nie. Dit was 'n geheim."

Hierdie drie vroue het elkeen op 'n unieke wyse betekenis geheg aan die seksuele molestering. Hartman en Burgess (1993:49) dui in dié verband daarop dat ' $n$ kind se betekenissisteem gekompromitteer kan word om herhaaldelike seksuele molestering te akkommodeer. 'n Rasionaal word daarvoor ontwikkel en sodoende word die illusie van beheer geskep. Op dié wyse word konstrukte geskep waarmee hulle die seksuele molestering hanteer en dit dien as ' $n$ wyse om betekenis uit die verwarrende gebeure te skep. Mart, Chanene en Brandy kon eie unieke konstrukte skep waarmee hulle die verwarrende gebeurtenis van seksuele molestering in hulle lewens probeer hanteer het. 
Die persoonlike konstruksies van al drie die deelnemers reflekteer hulle innerlike logika om deur middel van deduktiewe of induktiewe beredenering unieke betekenis uit die gebeure af te lei (Miltenburg \& Singer, 1997:42). Die inhoud van die betekenis wat elkeen van die drie vroue aan die gebeure geheg het, reflekteer ook die gedagte van Berlin (1996:326) dat individue betekenis konstrueer wat hulle gevoel van sekuriteit en oorlewing verhoog en as hulle doelwitte dien.

\subsection{Die ko-konstruksie van betekenis tussen die slagoffer en die oontreder}

Hierdie deel van die ondersoek fokus op die betekenis wat die deelnemers saam met die oortreder gevind het aangaande die seksuele molestering. Al drie die deelnemers het aangedui dat die oortreder nooit aan hulle enige redes gegee het waarom hy hulle seksueel gemolesteer het nie. In hulle verhouding met die oortreder was die ko-konstruksie van geheimhouding egter voorop. Al drie deelnemers sukkel steeds om as volwassenes die "geheim" met ander te deel.

Mart: $\quad$ "... en hy het vir my gesê om nie vir my ma te vertel nie, dit is ons geheim. My pa het ' $n$ kort humeur gehad. Ons het grootgeword met die idee dat jou pa en ma die sê het, jy praat nie terug nie. Nee, ek het nooit met haar daaroor gepraat nie. Ek dink ek was so gekondisioneer met: 'Moenie jou ma vertel nie, moenie jou ma vertel nie', dat die woorde oor en oor in my kop gespeel het. Ek was te bang om my mond oop te maak, miskien kon ek die verkeerde ding sê."

Chanene: "Hy het my ma gedreig dat hy my sou doodmaak soos hy my broer doodgemaak het as sy enige iets sê. Hy sal ons doodmaak. My ma was nie toegelaat om te praat oor die dinge wat hy gedoen het nie. Sy het een keer probeer om vir die buurman wat in die woonstel bokant ons gebly het te vertel. Toe hy uitgevind het, het hy my ma vir 'n lang ruk in die maag geskop. Sy was swanger met my broer en hy het afgekom en ons kon hom nie red nie. Hy het my in ' $n$ hoek gedruk en my gedwing om te kyk hoe hy haar verkrag. Ek het gesien hoe hy my ma geslaan en gesteek het met ' $n$ mes, terwyl hy seksueel met haar besig was."

Brandy: "Hy het keer op keer gekom en in die kamer ingekom. Hy was 'n polisieman. Hy het sy geweer gevat, langs die bed neergesit en tussen die lakens ingeklim. Hy het vir my gesê as ek vir enige iemand vertel, sal hy 'n vreeslike ding met my doen. Ek sal selfs sterf, veral as sy vrou moet uitvind." 
RL. van Niekerk \& H.G. Pretorius

Dit is duidelik dat al drie vroue deur outortitêre figure deur middel van vrees afgedreig is om sodoende die geheim van hulle seksuele dade te bewaar. Berlin (1996:326-327) wys op die belangrike rol wat ander mense speel om vir kinders te vertel of te wys wat dinge beteken. Op dié wyse vestig hulle ' $n$ raamwerk waarbinne verstaan kan word wat gebeur het. Mart, Chanene en Brandy het nie van die oortreders inligting ontvang om hulle dade te verstaan nie, maar het geweet dat dit geheim gehou moes word.

\subsection{Die deelnemers se konfrontasie met die sosiale konstruksie van betekenis aangaande die seksuele molestering van kinders}

In Suid-Afrika word algemeen aanvaar dat seksuele kontak tussen 'n volwassene en 'n kind onaanvaarbare gedrag is wat deur verskeie groepe en instansies verbied word. Wanneer kinders dit vir die eerste keer hoor, word hulle met die sosiale konstruksie van seksuele molestering gekonfronteer. Mart se eerste kontak met die gemeenskap se betekenis aangaande seksuele molestering was deur middel van leesstof en interaksie met haar portuurgroep. Sy het in daardie stadium nog nie besef dat dit wat haar pa gedoen het, onaanvaarbare seksuele molestering was nie. Sy het dit eers besef toe sy reeds gewerk het. Sy beskryf haar reaksie op die besef dat hy verkeerd gedoen het as skokkend en verbysterend.

Mart: "Die dag toe dit my tref dat die dinge wat hy gedoen het verkeerd was, ek het gewerk, toe het alles ... dit het gevoel soos koue water wat in my gesig gegooi word. Ek het net geweet dat dit 'n verskriklike skok was. Ek het besef dat die dinge wat hy gedoen het, hoort tussen 'n man en sy vrou. Ek het dit nie toe as seksuele molestering gesien nie, maar ek het net besef dat dit verkeerd was. Dit moes nie so gewees het nie. Dit is nie reg tussen 'n pa en sy dogter nie."

Mart: "Ek het begin om myself in die toilet toe te sluit as ons twee alleen by die huis was. Ek onthou die eerste dinge wat ek gedoen het. Ek het toe nog in die huis gebly. Ek het van hom probeer wegvlug. Ek het alle kontak met hom vermy as ek van die werk af gekom het."

Chanene het met ongeloof gereageer toe ' $n$ onderwyser haar meegedeel het dat dit wat haar pa doen, verkeerd is. Sy het eers by haar ma, wat dit bevestig het, gaan seker maak. Dié inligting het haar verwar. 
Chanene: "Toe het die onderwyser vir my gesê: 'Nee, wat jou pa gedoen het, was verkeerd,' en sy het met my daaroor begin praat. Ek het huis toe gegaan en my ma gaan vra of dit waar is en sy het gesê: 'Ja, maar sy weet nie hoe om dit te hanteer nie'. Ek het vir haar gesê: 'Ek verstaan dit nie'."

Brandy se eerste kontak met die sosiale konstruksie van betekenis het haar tot die besef gebring dat sy ai die tyd verkeerd was met haar persoonlike konstruksie van betekenis. Sy het besef haar pa en die oortreder het vir haar gejok en het haar misbruik. Dit het 'n keerpunt in haar lewe gebring. Hierdie besef het haar probleme laat begin, in so mate dat sy in psigiatriese inrigtings opgeneem is. Sy kon dit tog later in haar lewe leer hanteer. Alhoewel dit baie moeilik was, kon sy ook leer om die baba wat sy van die oortreder gehad het te hanteer. Die betekenis wat die gemeenskap aan haar ervarings geheg het, het 'n verbysterende effek gehad op haar lewe, sowel as op die wyse waarop sy haar seksuele molestering as kind probeer hanteer het.

Brandy: "Ek het net na daardie inigtingspamflet gekyk, en op een of ander manier het dit my net getref soos ' $n$ bom, net ontplof en dinge het vir my helder geword. Dit is toe dat ek begin breek het en my situasie begin het. Dit is eers toe ek besef het dinge was verkeerd, dat my probleme begin het. Terwyl dit gebeur het en ek gedink het dit was normaal, het dit niks aan my gedoen nie. Ek het so misbruik gevoel daarna. Ek het hom op 'n manier vertrou, maar ek weet nie om watter rede nie, want die meeste van die tyd het hy my seer gemaak, maar ek het hom en my pa steeds vertrou. Ek het gevoel hy het my beroof van iets en dit is toe dat ek so misbruik gevoel het en toe het ek probeer selfmoord pleeg."

Al drie die vroue is eers later in hulle lewe gekonfronteer met die betekenis wat die sosiale gemeenskap aan die gebeure geheg het. Hulle het daarmee uitgevind dat die persoonlike betekenis wat hulle aan seksuele molestering geheg het, verskil van dit wat die gemeenskap daaraan heg. Dié paradoks het verwarring en onsekerheid oor wat reg en wat verkeerd was by hulle tuisgebring. Atwood (1997:19) is van mening dat sosiale konstruksies van betekenis verwysingspunte vir die individu word om te verstaan en betekenis aan gebeure te kan heg. Die inkongruensie tussen die drie deelnemers se persoonlike konstruksie van betekenis en die sosiale konstruksies van betekenis oor die gebeure het bygedra tot die verwarring wat by hulle gevolg het. Die proses waardeur kongruensie tussen die deelnemers se subjektiewe realiteite en die sosiale konstruksies bereik kon word (Atwood, 1997:19), het vir die deelnemers onmoontlik geword. Dit verklaar die verbysterende 
R.L. van Niekerk \& H.G. Pretorius

reaksies van die drie vroue op hulle konfrontasie met die sosiale konstruksies aangaande seksuele molestering.

\section{Bespreking}

Die deelnemers aan hierdie ondersoek het aanvanklik ' $n$ ander betekenis aan hulle ervarings toegeskryf as wat die sosiale gemeenskap daaraan toeskryf het. Dit was egter 'n hanteringsmeganisme vir 'n gebeurtenis waaroor hulle geen inligting gehad het nie. Al drie die deelnemers het seksuele molestering as kinders beleef voordat hulle toepaslike kennis van seks en seksualiteit gehad het. Dit verklaar die aanvanklike verwarring wat beleef is. Alhoewel die ervaring van die molestering baie ongemak en pyn vir hulle veroorsaak het, het al drie deelnemers ' $n$ eie unieke betekenis aan die gebeure geheg in 'n poging om hulle molestering te kan hanteer. Dit reflekteer hulle eie innerlike logika om die gebeure te kan verstaan, hanteer en op dié wyse sekuriteit te beleef - al is dit 'n subjektiewe realiteit wat hulle geskep het.

Wells (1986) wys daarop dat kinders afhanklik is van volwassenes om hulle in te lig oor die betekenis van gebeurtenisse en ervarings. Daarom is die ko-konstruksie van betekenis afhanklik van dit wat die oortreder daaroor aan sy slagoffers vertel het. Berlin (1996:326) dui op die belangrikheid van ander mense om aan kinders te vertel wat dinge beteken en in die proses te slyp aan die raamwerk waarbinne hulle die gebeurtenisse kan verstaan. Hierdie deelnemers kon nie in 'n gesprek met die oortreders betekenis aan die gebeure heg nie, maar het inligting van ander ontvang om betekenis daaraan te heg.

Hulle uiteindelike besef dat die gemeenskap die gebeure as onaanvaarbare misdade beskou, het hulle verwar. Hulle het aan die gebeure betekenis geheg in 'n poging om dit te kon hanteer. Die betekenis wat die gemeenskap daaraan gee, was dus nie wat hulle verwag het nie. Dit was vir hulle 'n paradoks wat dit moeilik gemaak het om die gebeurtenis te hanteer.

Die verskil in betekenis was van so 'n aard dat dit 'n dubbelbinding vir hulle veroorsaak het. ' $n$ Dubbelbinding is 'n situasie waarin twee opponerende boodskappe gestel word en waarin daar nie 'n keuse en 'n uitweg uit die situasie is nie (Bateson, 1978; Hoffman, 1981:20). So is die deelnemers aan die een kant gekonfronteer met die boodskap: "Dit is jou pa" en aan die ander kant met die boodskap: "Hy is ' $n$ seksuele molesteerder". Dit maak nie saak watter een van die boodskappe as waar aanvaar word nie - die ander kant kan nie sinvol daarin verreken word nie en die slagoffer kan nie uit die situasie ontsnap nie. 


\section{Slot}

Op grond van die ondersoek wat onderneem is, was dit duidelik dat betekenis op een of ander wyse verkry word in 'n proses van kommunikasie. Individue ko-konstrueer die betekenis van gebeure wat uiteindelik gevestig raak en op dié wyse sosiale konstrukte word. Lede van die samelewing gebruik dit om weer in hulle eie lewe betekenis aan gebeure te heg

Hulpverleners wat 'n diens verskaf aan seksueel gemolesteerde kinders behoort dus daarop bedag te wees dat kinders en volwassenes verskillende betekenisse aan gebeure kan heg. Hierdie betekenisse stem nie noodwendig ooreen met die aanvaarbare sosiale konstrukte en betekenis nie. Hulpverleners is egter deelnemers aan die proses om betekenis aan gebeure te heg en het die taak om kinders te lei om nuwe betekenis te vind - 'n nuwe betekenis waarin die sosiale konstrukte daaroor geïntegreer is.

Hulpverleners moet veral sensitief en empaties wees tydens emosionele katarsis wanneer kinders inligting bekom wat aandui dat die sosiale gemeenskap ' $n$ ander betekenis as hulle aan seksuele molestering geheg het. Seksuele molestering is een van die konstrukte waaraan kinders betekenis heg om 'n gebeurtenis waaroor hulle nie veel inligting het nie te kan hanteer. Die meedeel van die betekenis wat die gemeenskap daaraan heg, kan dus ontwrigtende gevolge vir die kind inhou indien dit nie reg hanteer word nie.

\section{Bibliografie}

ANON. 1999a. Thousands raped or assaulted last year, police statistics show Horrific figures of child abuse revealed. The Pretoria News, March 16.

ANON. 1999b. Child sex exploitation grows. The Sowetan, September 21

ATWOOD, J.D. 1997. Social construction theory and therapy. (In Atwood, J.D., ed Challenging family therapy situations: Perspectives in social construction. New York: Springer Publishing Company. p. 1-40.)

BARNETT, OW. MILLER-PERRIN, C.L. \& PERRIN, R.D. 1997. Family violence across the lifespan: An introduction. Thousand Oaks : SAGE Publications

BATESON, G. 1978 The birth of a matrix or double bind epistemology. (In Berger, M.M. ed. Beyond the double bind: Communication and family systems, theories, and techniques with schizophrenia. New York: Bruner/Mazel, Publishers.)

BERG, I.K. \& DE JONG, P. 1996. Solution-building conversations: Co-constructing a sense of competence with clients. Families in Society: The Journal of Contemporary Human Services, 77(3):376-391, June.

BERGER, P.L. \& LUCKMANN, T. 1966. The social construction of reality Harmondsworth : Penguin.

BERLIN, S.B. 1996. Constructivism and the environment: A cognitive-integrative perspective for social work practice. Families in Society: The Journal of Contemporary Human Services, 77(3):326-336, June.

BURR, V. 1999 An introduction to social constructionism. London : Routledge. 
DIXON, C.A. 1998. Sexual revictimisation in "coloured" female survivors of child sexual abuse: An integrated approach. Johannesburg : RAU. (M.A. Dissertation.)

DOMINELLI, L. 1989. Betrayal of trust: A feminist analysis of power relationships in incest abuse and its relevance for social work practice. The British Journal of Social Work, 19:291-307.

FORSTER, W. 1964. Palestinian Judaism in New Testament times. Edinburgh : Oliver \& Boyd.

GERGEN, K.J. 1994. Realities and relationships: soundings in social construction London : Harvard University Press.

GILGUN, J.F. 1994. Avengers, conquerors, playmates, and lovers: Roles played by child sexual abuse perpetrators. Families in Society: The Journal of Contemporary Human Senvices, 75(5): 467-480, October.

HARTMAN, C.R. \& BURGESS, A.W. 1993. Information processing of trauma. Child Abuse and Neglect, 17:47-58

HOFFMAN, L. 1981. Foundations of family therapy: A conceptual framework for systems change. New York: Basic Books.

HOFFMAN, L. 1990. Constructing realities: An art of lenses. Family Process, 29(1):112.

JEHU, D., KLASSEN, C. \& GAZAN, M. 1986. Cognitive restructuring of distorted beliefs associated with childhood sexual abuse. Journal of Social Work and Human Sexuality, 4:49-69

KRITZINGER, C. 1995. Problemising pleasure: Radical feminist deconstructions of sexuality and power. (In Radtke, H.L. \& Stam, H.J., eds., Power/gender. Social reflections in theory and practice. London : SAGE Publications.)

KRITZINGER, J. 1988. Defending innocence: Ideologies of childhood Feminist Review, 28:77-87.

LEVETT, A. 1988. Psychological trauma: Discourses of childhood sexual abuse Cape Town : UCT. (D. Phil. Dissertation.)

MABUSELA, S. 1994. Child abuse in South Africa. (Paper delivered at the United Nation Expert Group Meeting, Children and juveniles in detention: Applications of human rights standards. Vienna, Austria.)

MACLEOD, M \& SARAGA, E. 1988. Challenging the orthodoxy: Towards a feminist theory and practice. Feminist Review, 28:16-55.

MARSHALL, A. \& HERMAN, V. 1998. Child sexual abuse in South Africa Johannesburg : RAPCAN

MASTERS, W.H., JOHNSON, V.E. \& KOLODNY, R.C. 1992. Masters \& Johnson on sex and human loving. Hong Kong : Papermac

MILTENBURG, R. \& SINGER, E. 1997. A theory and support method for adult sexual abuse survivors living in an abusive world. Journal of Child Sexual Abuse, 6 (1):39-63.

MISDAADINLIGTINGANALISESENTRUM. 1999. The incidence of serious crime January to December 1998. Pretoria : SAPD.

NEVID, J.S., FICHNER-RATHUS, L. \& RATHUS, S.A. 1995. Human sexuality in a world of diversity. Boston: Allyn and Bacon

OWEN, I.A. 1992 Applying social constructionism to psychotherapy. Counselling Psychology Quarterly, 5(4):385-402.

WELLS, G. 1986. The meaning makers: Children learning language and using language to learn. London: Hodder \& Stoughton.

Wet No. 23 of 1957. Die Wet op Seksuele Oortreding. Pretoria : State Press. 
Die konstruksie van betekenis by seksuele molestering

\section{Kernbegrippe:}

ko-konstruksie van betekenis

seksuele molestering

sosiale konstruksionisme

vroulike slagoffers - seksuele molestering

\section{Key concepts:}

co-construction of meaning

female survivors of sexual abuse

sexual abuse

social constructionism 